\title{
Ecosystem under restoration: a sustainable future for the cultural landscape of San Antonio River, Texas
}

\author{
A. Lombardi \\ University of Texas at San Antonio, USA
}

\begin{abstract}
The city of San Antonio is one of the most relevant historic cities in the US, world-wide renown as the 'Venice of Texas', characterized by its river and famous Riverwalk.

The city was founded by the Spaniards as a presidio in the first quarter of eighteen century in a strategic location between two water features: the Rio San Antonio and the Arroyo de San Pedro. During the same period, were built along the river five Spanish-colonial missions, which are today, together with their 'cultural landscape', on the US tentative list to be advanced as a possible UNESCO World Heritage Site.

The famed Riverwalk, created in the 30 s after the construction of the Great Bend, is a unique experience of a river park within the city, but it has a limited extension, related only to the downtown area.

After 1941 flood, the 1954 Corps of Engineers channelization project drastically transformed the river landscape outside the city center: river channelization effectively protected the area from destructive floods, however, changed the river into a drainage channel. Without taking in consideration Leopold's 'land ethic', it interrupted the ancestral and laborious relationship between land and water.

This study analyzes 2001-2014 San Antonio River Improvement Project (SARIP) and subsequently focuses on the undertaken strategies for the 'Mission Reach Ecosystem Restoration Project'. SARIP enhances 13 miles of the river both north and south of downtown, the latter recovers an eight mile stretch of the river on the southern area of the city. It includes several steps assessed in this research study:
\end{abstract}


- flood management and reconfiguration of the river channel, criteria and limits;

- improvement of the river's ecology including aquatic habitat;

- restoration of the flora, reestablishing hundreds of acres of native grasses and wildflowers and reintroducing native trees and shrubs.

An ecosystem restoration changes the relationship between man and land: it will enhance inhabitants' circulation along the river beyond the Riverwalk, it will recreates the historical connections, interrupted for more than 50 years, to the Missions and, will re-link river banks and its surrounding land.

The culmination of these steps will result in an environmental sustainable water source, giving new meaning and new role to the river for future generations to come.

Keywords: San Antonio River, cultural landscape, ecosystem restoration, Franciscan Missions.

\section{Introduction}

Between the $16^{\text {th }}$ and $18^{\text {th }}$ century, the process of conformation of the northern frontier of New Spain was extremely complex and long lasting. The Spanish Crown made enormous efforts for its definition because of the far distance of the lands to be controlled, their geographical characteristics, the human groups inhabiting these lands as well as international pressures. In this context, in the first quarter of eighteen century, the city of San Antonio was founded as a presidio between two water features: the Rio San Antonio and the Arroyo de San Pedro (today known as San Pedro creek) and, in the course of the $18^{\text {th }}$ century, five Franciscan missions were built along the river.

The narrow river, although not navigable to the ocean, offered an oasis of sorts on this far northern frontier of New Spain: creeks, springs, farmland, and a temperate climate all were factors leading to the foundation of a settlement, to be destined to become the ninth largest US City [1].

The five $18^{\text {th }}$ century Franciscan Missions cultural landscape is presently on the US "tentative list" to be advanced as a possible UNESCO World Heritage Site in 2016. This cultural landscape can be considered as one of the still existing best models of the culmination of Spain's design for its mission empire. It includes the complexes of the five Spanish Colonial mission - San Antonio de Valero (Alamo), Concepcion, San Jose, San Juan Capistrano, and Espada - built along a 12 miles section of the San Antonio River basin. The Spanish Crown intended to create self-sustaining, socio-economic units, supporting the establishment of missions as transitory ecclesiastical settlements that would develop into permanent secular communities in defense of the territory against incursions by other European states [2]. The construction of an extensive water distribution system of acequias (water ditches), built by the Spaniards since the first half of 18th century, witnesses the high-skilled engineering system for land irrigation and the interchange between indigenous populations, missionaries and colonizers who were able to develop their settlements in deep connection with the San Antonio River [2]. 
Downtown San Antonio is characterized by its famous 'Riverwalk' and historic neighborhoods. However, beyond the Riverwalk, miles of river remained undeveloped within the city limits, yet deeply altered by interventions which aimed at preventing river floods. This paper examines the role of San Antonio River and its transformation throughout its history, including the 1954 Corps of Engineers channelization project until the 2001-2014 San Antonio River Improvement Project (SARIP), and analyzes Mission Reach Ecosystem Restoration Project, which involve reconfiguration of the channel and flood management, recreation of the native landscape and river's ecology, park facilities and infrastructure and, historical connections and public art.

This complex ecosystem restoration project aims to recreate, at large spatial scale, the features and the natural balance of the historic landscape characterizing this area for centuries involving also complex stakeholder and public roles.

The River Improvement Project reconnects the historic core of the city to the Missions along the river allowing people's circulation beyond the downtown area, and creating a corridor 13 miles long which reconnects several historic facilities, some of them to be involved in future urban regeneration process.

\section{Relevance of the San Antonio River}

The first documented arrival of Spanish explorers at the river occurred at the end of the 1600s: some members of a Spanish expedition celebrated Mass on the banks of the river on June 13, 1691, Feast Day of Saint Anthony. During the religious function, Franciscan priest Damien Massanet renamed the waterway 'San Antonio'.

Spanish Missionaries and colonists built acequias, a series of dams and handdug ditches which served to bring river water to the missions and to the original civic settlement. They are considered some of the earliest recorded engineered water systems in the nation, shaping the landscape for more than two centuries. A system of eight acequias related to the San Antonio River is documented since 1718 , and was an effective water distribution system for nearly 200 years, allowing the irrigation to surrounding land for farming and pastures for the missions and for civilians. The acequias, together with some creeks and the river, allowed the growth of the urban settlement, providing potable water.

The term acequia is derived from the Arabic alsaqiya, its ethimology clearly reveals an Arab origin of this construction technique, which was most probably brought to Spain [3]. Ancient maps and documents, however, identify an artificial water ditch, built prior to the arrival of the Spaniards, constructed by the Amerindians who populated this area.

The River South Area is the home of the oldest continuously functioning Spanish colonial dam and acequias. Within the River South Area the oldest priority water rights in the State of Texas originated from mission agricultural use and continue to influence land use in and around the missions [1]. Since the 1800s, the San Antonio River has experienced flooding problems due to its geographic location, increasing population in the area, and its related infrastructure improvements that lead to increasing rainfall runoff [1]: Spanish records reflect 
that the flood of 1819 swept through many homes in its path. Other floods arrived in $1865,1880,1899$ and 1913, a deadly flood in 1921, a major flood to San Antonio's downtown district in 1946, and the most recent floods of 1998 and 2002 [4].

In particular, the 1921 flood sign a turning point in the history of the river: In September 8, 1921 a sudden, hard rainfall over the Olmos Basin and San Antonio River resulted in over 9 feet of water downstream in the center of the city, causing flooding that killed 50 people and millions of dollars in damages [1]. The local community made historic and controversial decisions to implement flood control measures: \$ 2.8 million bond were issued for constructing a dam and straighten the streams. The Olmos Dam, a concrete wonder 80 feet high and 1,925 feet long was built in 1925; The Great Bend's cut off channel, as wide as the Great Bend itself, located in the core of the historic area, was completed in 1930 [5].

The river park had its first permanent 'Riverwalk' in 1928, the following decades saw continuous improvements to the downtown segment of the river with the development of a more extended Riverwalk, inspired by Robert H.H. Hugman -city architect- who saw San Antonio River as a chance to exploit the city's Spanish heritage with commercial activities and open spaces [6].

Descriptions of old cities of Spain, Mediterranean architecture, as well as Xochimilco, Mexico City's water gardens were its inspirations. In 1929, Harlam Bartholomew was hired and he envisioned for the river to maintain a more natural, contemplative linear park through the heart of the busy city. The Depression, however, had plunged downtown San Antonio into a slump from which it would recover in forty years, so that Hugman's and Bartholomew's plans were only partially realized [5]. Despite the Depression, the city did not abandon the river 'beatification': the Alamo's battle centennial was celebrated, and the celebrations included the first "Venetian Carnival" on the river, along the cut-off channel.

In 1937 a public office for the protection for the river was created: San Antonio River Canal and Conservancy District, then renamed in 1953, the San Antonio River Authority (SARA). SARA is charged by the state of Texas to preserve, protect and manage the resources and environment of the San Antonio River and its tributaries. [7].

From 1939 through 1941, the pilot channel was deepened, three dams were built, underground drains constructed, and flood gates installed at both ends of the river loop. Landscape features included stone walkways, stairwells and footbridges. Also added was an outdoor theatre - the Arneson - where stage and seats are divided by the river. Preservation of indigenous tree and plants was undertaken, and Hugman's northern flood gate was adorned with arches and an arbor that lend an Old World Spanish flair. San Antonio's famous Riverwalk was born [4].

A second devastating flood in 1946 prompted a comprehensive flood study by the US Army Corps of Engineers completed in 1951. This study recommended the channelization or straightening of 31 miles of the river and its tributaries, the project was named the San Antonio Channel Improvement Project (SACIP) and authorized by Congress for being implemented by the Corps of Engineers in $1954[1]$. 
Although the works undertaken were an effective way of managing flood water, they did not take into consideration Leopold's 'land ethic' which does prevent the alteration, management, and use of natural 'resources,' but it does affirm their right to continued existence in a natural state [8]. Leopold's land ethic is a pivotal point in America's environmental awareness since it asserts that the role of 'Homo sapiens' has to develop from conqueror of the land-community to plain member and citizen of it, respecting for his fellow-members, and also respect for the community as such [9].

The effects of the reconfiguration of the channel of San Antonio River, beyond the effective flood control, was the irreversible alteration of the traditional land use and subdivision as well as the damage of the ecosystem of the river.

In order to protect the Paseo del Río from uncontrolled flooding, the San Antonio River Authority together with the Corps of Engineers, in 1982, began, to consider the feasibility of a bypass system to divert flood water through two tunnels to be built under the downtown area, below river and the arroyo de San Pedro. Tunnel construction began in 1988, and ended in 1995, it is 24 feet 4 inches in diameter 3 miles in length [10]. The first projects focused on the protection of the downtown area, not including the River South, characterized by a low-density population [1].

In 2001 the scope of work transitioned to the broader San Antonio River Improvements Project (SARIP) which identified "environmental restoration and recreation as project purposes" [11] and is inspired by a community-based vision with a holistic, regional approach to manage flood control, storm water and water quality [7].

\section{River Improvement Project}

The San Antonio River Improvements Project (SARIP) is \$358.3 million investment that targets 13 miles of river banks. The multi-phase project focuses on improving the long-neglected river, north and south of downtown, to become a walkable, bike able linear urban park, and it is divided in three sections: the fourmile Museum Reach north of downtown, the one-mile Eagleland and eight-mile Mission Reach south of downtown [4].

Specific objectives for the Museum Reach, which is the urban segment of the project, are extending the amenities of the world-famous San Antonio Riverwalk up through Brackenridge Park, for connecting cultural institutions and commercial centers via a linear park. The Museum Reach is designed by the San Antonio based firm Ford, Powell and Carson and sees its completion in 2009 [12]. It provides public access to the river, reconnecting the neighborhood to water. The creation of this capacity is expected to lay the foundation for commercial, residential and retail construction in the area, to spur a renaissance of urban development [13]. A 1.3 mile stretch of new walkways, landscaping and public art includes a dam for barge access and a lock, and links numerous commercial, historic and cultural institutions such as San Antonio Museum of Art - former late 19th century Lone Star Brewery - and the Pearl brewery area that is becoming one of the top culinary, cultural and urban living destination of San Antonio [12]. 
The Eagleland and Mission Reach segments, however, are characterized by low-density urbanization and vegetation has been destroyed since 1954 US Army Corps of Engineers project.

Few original topographical features are remaining. The project in these areas aims to restore native habitat and the natural meander of the river, along with developing new recreational opportunities. These enhancements are expected to have a broad oriented impact and far-reaching benefits for all of San Antonio, from increased economic development to cultural resources and recreational opportunities connecting neighborhoods [4].

The following part of this study focuses on the Mission Reach Area, the eightmile section of the river, extending from Lonestar Boulevard south to Loop 410 South.

\subsection{Mission Reach Ecosystem Restoration and Recreation Project}

The Mission Reach Ecosystem Restoration Project is the primary focus for improvements on the 8-mile Mission Reach segment and its striking impact on city development can be already appreciated since its recent completion in October 2013. The project guidelines for the whole segment were developed by SWA Group of Houston and follow the vision developed in the course of 15 years by the River Oversight Committee, composed of members of business and neighborhoods along the rivers [12].

The project included several steps whose culmination results in an environmental sustainable water source, connected with the surrounding city landscape in numerous locations like parks, neighborhoods, commercial development and cultural institutions [12].

\subsubsection{Flood management and reconfiguration of the river channel: criteria and limits}

Although river channelization is an effective way of managing flood water, it has damaged the ecosystem of the river beyond being visually unappealing. The Mission Reach Ecosystem Restoration project aims at correcting the damage done to the ecosystem by the channelization and restore the river's ecology while providing the same level of flood management that was attained by the channelized river [4].

River channel solutions intend to recreate the natural environment strongly altered within the last 60 years, with sinuous edges and minimizing the 'artificial' channel appearance. The project focuses on the ecosystem restoration, working on the fluvial geomorphology, which is the study of the processes and pressures operating on river systems, transforming the straightened river by adding sinuosity, where possible, while maintaining flood control, reducing erosion, re-introducing native vegetation and creating an environment more suitable for recreation and wildlife [4]. 


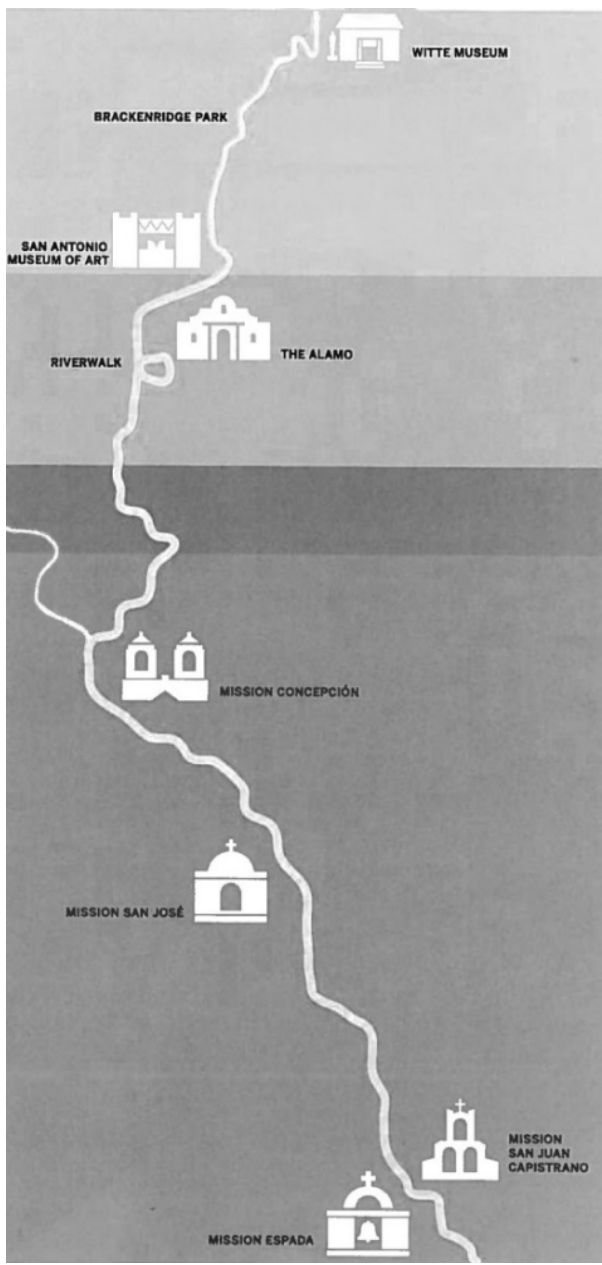

Figure 1: Extension of the riverbank improvements makes the Riverwalk more than six times longer (San Antonio River Improvement Map [4] edited by the author).

Design solutions utilize a variety of low flow conditions such as riffles/run/pools sequence, approximately 13 acres of embayments in the river and restoring approximately 113 acres of aquatic habitat. Over 3 million cubic yards of soil were removed in order to restore and recreate a more natural riverine environment [4].

The original natural river meanders, however, obliterated around 50 years ago with the channelization, cannot not be reconstructed: Community must be aware that, through this ambitious project, a 'restoration' only of the ecosystem was undertaken and not a 'restoration' of the river historic landscape, which is nowadays impossible to recreate since interventions are limited to the flood 
control channel limits. Citizens and visitors will not be able to experience the river cultural landscape as it appeared in the past, with its vast and sinuous meanders. The historic landscape, especially the one characterizing the $18^{\text {th }}$ century Missions area, can still be visible only in some confined locations, like the ones where the acequia system is still working.

The types of design solutions developed for the Mission Reach Ecosystem Restoration project create an alternating sequence of several river channel habitat types - runs, riffles, pools and embayments - usually characterizing balanced environmentally rivers to support a variety of ecosystem functions and aquatic wildlife [1].

Runs - Runs are areas of the river with average depth and velocity. After flood control channelization, the San Antonio River consisted entirely of runs. Runs, in an environmentally balance river, generally connect riffles and pools. The Mission Reach project restores the structural diversity of the river [4].

Riffles - A riffle is a shallow area of river with a substrate consisting of rocks. Water usually runs quickly over these areas, creating a choppy surface. Riffles help oxygenate the water, serve as an area to protect fish from predators and are a place where many insect species reproduce or grow to maturity. Some fish species for which riffles are particularly important include the central stoneroller, red shiner, speckled chub, channel catfish, orange throat darter and the Texas logperch [4].

Pools - Pools are deep areas of water where currents move slowly. They generally occur after a run structure, and sediment tends to accumulate at the far end of a pool, creating overtime the creation of a new riffle. Pools play a critical role in maintaining water quality in the river by removing impurities from the water, such as sediments, whose reduction benefits a variety of aquatic organisms. Pools also provide great habitat for different aquatic animals than those found in riffle structures, like larger species of fish. In case of drought conditions, when the water level drops, pools provide effective refuges for fish until the water level rises. The deeper areas provided by pools moderate water temperature during high temperature months and are ideal habitat for the species of fish preferring cool conditions [4].

Embayments - An embayment is a still, crescent-shaped body of water, formed when a curve in the river becomes separated from the river. Embayments were once a natural part of the San Antonio River system and were commonly found on the river's floodplain. Because the water in embayments does not flow, it supports myriad of aquatic plants and animals species adapted to still water bodies. Embayments also help to improve water quality: When water from stormwater inflows is directed to these areas, it is forced to remain in the embayment because of its low flow velocity for a period of time during which water is processed and cleaned [4].

\subsubsection{Improvement of the river's ecology and restoration of flora}

The Society for Ecological Restoration defines ecological restoration as an intentional activity that initiates or accelerates the recovery of an ecosystem with respect to its health, integrity and sustainability. The Mission Reach Ecosystem 
Restoration Project is focused at increasing the quality, quantity and diversity of flora and fauna along the eight miles of the San Antonio River Mission Reach area, and includes the restoration of approximately 334 acres of riparian woodland habitat [4].

Restoring a healthy ecosystem along this area is a delicate balance between planting appropriate native plants and maintaining efficient floodwater conveyance.

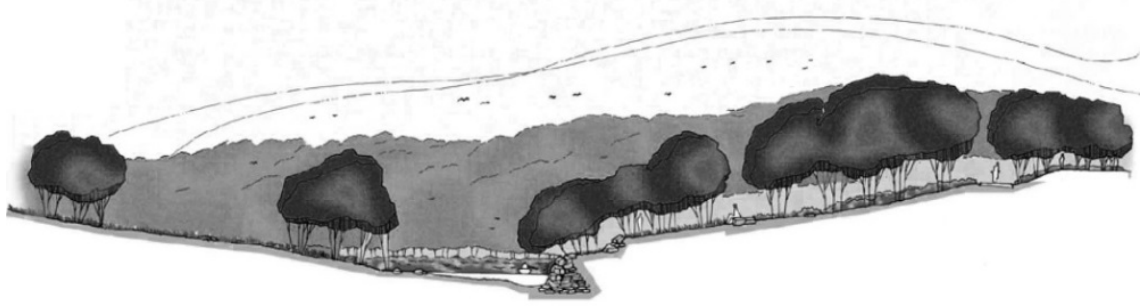

Figure 2: Section (not to scale) of the San Antonio River channel in the Mission Reach area after Ecosystem Restoration (from SARIP Design Guidelines, San Antonio, 2001, p. 24 [4]).

New tree masses are being planted including native and indigenous species, and whenever possible, existing tree masses are preserved: over 20,000 young trees and shrubs, 39 native tree and shrub species as well as over 60 native grass and wildlife species. In order to plant additional trees within the flood control channel, additional floodwater capacity was added in the adjacent land owned by public entities.

Native plants play a crucial role in ecosystem restoration by controlling erosion on the banks of the river. Their long root systems hold soil in place and aid in improving water quality by filtering out storm water runoff before it enters the river. Native plants also provide food and habitat for native wildlife which leads to increased wildlife in the area. Native plants species have been attentively selected through a deed research based on literature review and analysis of sites where the ecosystem is still intact such as Salado Creek, Goliad State Park, Las Cabras, and others [4].

The Mission Reach vegetation plan has been designed to mimic the diversity and density of native riparian woodlands that exist naturally under both drought and flood conditions. To achieve this balance, four main vegetation type areas, varying in tree and shrub density, have been proposed:

- Zone A - 250 trees per acre - which was the most natural condition over time - these denser areas are usually further from water;

- Zone $\mathrm{C}-70$ trees per acre - with native grass understory in most location;

- Zone D - 27 trees per acre - with native grass understory everywhere, and more "park like" tree density; and

- Zone E-herbaceous vegetation only - no trees [14]. 
Vegetation placement follows two main criteria: One is to restore the natural habitat features, the other one is to recreate a recreational environment. Tree placement considerations are based on the analysis of soil moisture, which depends on the distance from the water and seral stages (early mid or late seral).

Nurturing an ecosystem comprised of native plants requires the regular extermination of non-native invasive plant species. Long-term operations and maintenance is critical to the success of the project.

Trees were planted approximately two years after each phase of the Mission Reach is open, to give the vegetation time to become established. Young, small trees were planted since more resistant to flooding.

The Mission Reach looks much different than the 'Riverwalk' and the new Museum Reach area of the river north of downtown. The native landscape is intended to look wild rather than manicured. Grasses and wildflowers will be allowed to grow to their natural heights rather than mowed. Although the landscape is ready to enjoy now, it will take approximately 50 years for the trees and vegetation to fully mature and to fully see completed the entire ecosystem restoration process [4].

\subsection{Historical connections and public art along the river}

Along the Mission Reach stretch of the Riverwalk, four of the San Antonio's Spanish Colonial Missions emerge: Mission Nuestra Senora de la Purissima Concepcion de Acuna, Mission San José y Miguel de Aguayo, Mission San Juan Capistrano and Mission San Francisco de la Espada. Uniquely clustered along the river, these $18^{\text {th }}$ century landmarks, the oldest buildings in the region, together with their extensive water distribution system, stand as the "most complete and intact example" in the former frontier of Spain's North American colonial empire [2].

The Mission Reach Ecosystem Restoration Project recreates the historic and cultural connections between the river and the San Antonio Missions National Historical Park, also providing improved quality of life and recreational access to the river [13].

The 1933 Comprehensive Plan for San Antonio already recommended connecting the historic Spanish Missions. The importance of linking the Missions became a key local effort in 1953 by the San Antonio Conservation Society and Archdiocese of San Antonio, commissioning Robert H. H. Hugman a study to for the beautification of the historic Spanish Missions by connecting them with a landscaped parkway. In 1959, another plan was presented by nationally renowned planning consultant, Sam Zisman, who proposed developing a scenic park roadway. The program was reinvigorated in 1962 with the Mission Parkway Master Plan [1].

The establishment of the National Park in 1978 cemented the historical and cultural significance of these sites and helped to implement the historical connections envisioned since the 1930s as well as the continued preservation of the missions' buildings [15].

Spanish Colonial resources of San Antonio are focal points of the River South area and the Mission Reach Ecosystem Restoration project makes the river more accessible to neighborhoods by creating eight street connections. 
Rialto Studio of San Antonio is in charge for the design of those connections as a consultant of the SA River Authority, these works are funded by venue tax with a contribution of $\$ 125$ million [12].

For Mission Concepcion, for example, the first to be encountered coming from the downtown Riverwalk, the connection consists in a realignment of the Theo street, with the creation of a direct walking connection. The construction of a tall, circular sandstone portal at the top of the east bank in the expanded Concepcion Park allows to engage a visual connection circa one quarter mile away [12].

The community is also committed to increasing the boundary of San Antonio Missions National Historical Park envisioned since the 1930s. A proposal has been presented to the United States Congress by local leaders to increase the boundary of the existing park lands designated as a national park along the San Antonio River. The proposal is to establish these parcels as a comprehensive Spanish colonial site, the largest in the world. This initiative is tightly timed for completion to meet the National Park Service centennial anniversary in 2016 and the potential designation as World Heritage Site [1].

At the confluence between the San Pedro creek and the river, a park is under construction - Confluence Park - funded by the San Antonio River Foundation and designed with the consultancy of the artist Stuart Allen, whose work is part of the Museum Reach. Rain water capture and reuse throughout the park become the occasion for creating public art with an undulating pavilion funneling water into a cistern [12].

Other historic resources to be reconnected through the Mission Reach Ecosystem Restoration Projects are constituted by several industrial heritage buildings, which testify an important phase, even though more recent, of the history of the city: the Lone Star Brewery and the Blue Star Complex on the city's near South side and the circa-1909 Mission road power plant a little bit further south.

Over time property values of land closer to the river and to historic landmarks will raise and the demand for new and revitalized real estate development will increase, thus creating a more desirable living and working environment for area residents. These areas will keep the actual historic character of the settlement, with low density residential structures.

\section{Conclusion}

Transformations history of San Antonio River witnesses the alternating relationship between man and his environment as well as the evolving approach to land use patterns over time. During the 20th century, the man's need of protection from continuous floods led to interventions which drastically modified the natural features of the river landscape and destroyed the ecosystem balance. The pre-industrial man's use of natural resources, conceived in balanced relationship with nature, was lost forever.

The SARIP shows that the community has understood the necessity to recreate a more balanced environment for a sustainable future and the completion of the Mission Reach Ecosystem Restoration Project represents the culmination of 
decades of efforts, reconnecting citizens to their natural resources with the riparian woodland ecosystem restored. It infuses a renewed vitality to into the South town neighborhoods that flank the river, in particular the ones connected with the Missions complexes which represent a major legacy with recognized 'outstanding universal values'.

The Mission Reach Ecosystem Restoration Project impact is foreseen to be amazing at a broader scale, driving back the inhabitants to use their natural resources and to rediscover and preserve with a renovated awareness their cultural heritage. Since specific developed land uses have not been projected for the Mission Reach, an exact estimate of the potential economic impacts is premature.

However, it is clear that projects in the Mission Reach will have an incredible positive effect on San Antonio's economy that extends well beyond the impact of the construction itself. Taken together, the projects of the Mission Reach enhance the recreational assets of San Antonio and reconnect the rich historical resources of the area, also listed as a UNESCO World Heritage Site, sparking a virtuous sustainable urban regeneration process of the South town underdeveloped neighborhoods.

\section{References}

[1] San Antonio River South Area Coordinated Management Plan, ProtectPromote-Coordinate, 2010. http://www.sanantonioriver.org/images/ RiverSouth_Management_plan_12_08_2010.pdf (retrieved 03/28/2013).

[2] San Antonio Missions, Texas, United States. Nomination to the World Heritage List by the United States of America, San Antonio, Texas, 2014.

[3] Cox, W., The Spanish Acequias of San Antonio, Maverick Publishing Company, San Antonio, 2005.

[4] San Antonio River Improvement Project, http://www.sanantonioriver.org (retrieved 04/02/2013).

[5] Fisher, L.F., Riverwalk. The Epic Story of San Antonio's River, Maverick Publishing Company, San Antonio, 2007.

[6] G. V. Zunker, A dream come True: Robert Hugman and San Antonio's Riverwalk, rev. ed. N.p, San Antonio, 1994.

[7] San Antonio River Authority, http://www.sara-tx.org/ (retrieved 04/03/2013).

[8] Leopold, A. A Sand County Almanac: And Sketches Here and There, Oxford University Press, New York, 1949.

[9] Jordan, W.R., Gilpin, M.E., Aber, J.D., Restoration Ecology. A Synthetic Approach to Ecological Research, Cambridge University Press, Cambridge, 1987.

[10] Fisher, L.F., Saving San Antonio: the Precarious Preservation of a Heritage, Texas Tech University Press, Lubbock, 1996.

[11] Public Law 106-541, Water Resources Development Act of 2000, Sec. 335: San Antonio Channel, San Antonio, Texas, December 11, 2000, http://www.fws.gov/habitatconservation/Omnibus/WRDA2000.pdf (retrieved 04/03/2013). 
[12] Hamilton, T. I., Mission Reach. In: Texas Architect, 64-01, January/February, 2014, pp. 43-47.

[13] TXP, Inc., Assessment of the Potential Impact of the San Antonio River Improvements Project / San Antonio River Foundation, 2007, http://www.sariverfoundation.org/sites/default/files/Econ-Impactfullreport.pdf (retrieved 02/02/2014).

[14] US Army Corps of Engineers - Fort Worth District, San Antonio Channel Improvement Project Mission Reach, Restoration of the Riparian Corridor in an Active Floodway, http://www.cbnp.us/images-81/usace-missionreach.pdf (retrieved 02/03/2014).

[15] Wright, R., Worthy of World Heritage. In: Texas Architect, 64-01, January/February, 2014, pp. 79-83. 